IRSH 52 (2007), pp. II 5-I 32 DOI: I0.1017/S0020859007003 I5X

(C) 2007 Internationaal Instituut voor Sociale Geschiedenis

\title{
Humour as a Guerrilla Tactic: The West German Student Movement's Mockery of the Establishment*
}

\author{
SIMON TEUNE
}

Summary: A small group within the German student movement of the rg6os expressed its critique of society in humorous protests that condensed the urge for a non-materialist, individualistic, and libertarian change. In the early phase of an emerging cycle of protest, Spassguerilla [fun guerrilla] contributed to shaping the face of the student movement, despite differences with the more traditional groups within that movement. In happenings, pamphlets, and judicial trials, humorous activists derided conventional ways of thinking and living. A responsive environment played a decisive role in shaping the image of the insurgents, thus reinforcing the impact of their actions and drawing in sympathizers.

\section{INTRODUCTION}

Humour and amusement are probably not the first associations one would make with reference to politics in postwar West Germany. On the contrary, the young state was characterized by a rigid conservatism and the legacy of authoritarianism continued to prevail. Yet a certain type of humour is a telling expression of the political and cultural transformation the country experienced in the I960s. At the intersection of bohemian circles and anti-authoritarian neo-Marxist currents, the concept of Spassguerilla [fun guerrilla] developed as a witty take on society. The disrespectful behaviour of activists challenging the authorities and takenfor-granted social rules became a sign of a society in transformation. This article will approach humorous forms of protest by focusing on an organizational nucleus of Spassguerilla, Kommune I. Three of their protests will be referred to in order to understand the tactical concept and the environment with which it reacted.

This article aims to provide answers to the following questions: What

\footnotetext{
* I am indebted to the research group, "Civil Society, Citizenship and Political Mobilization in Europe” at the Wissenschaftszentrum Berlin für Sozialforschung (Social Science Research Center Berlin) for a lively and fruitful discussion of an earlier version of this paper. I would also like to thank Andrew Tompkins for applying his linguistic skills to the original manuscript.
} 
were the conditions in which this new kind of activism emerged? What was the public perception of this phenomenon (and how was its image constructed ex post)? And, lastly, what form did the reaction to this challenge take? Before these questions are tackled, we shall reflect on the use of analysing humour in social movements.

Abundant research into humour has underlined the central role of this phenomenon in both constructing and deconstructing meaning in everyday life. Beyond its relief function, humour is known to be a means of bringing power relations to the surface. Research shows that in powerridden environments, be they in the business world or totalitarian regimes, jokes are an everyday form of communication to articulate discontent and visualize injustice in a less offensive way. ${ }^{\mathrm{I}}$

Obviously, the focus on humour as a way to express grievances can also enrich the cultural analysis of social movements. We may, however, assume that social movements as agents of social change do not typically rely on "reinforcing humour" that affirms the given social order, but rather on "subversive" forms. ${ }^{2}$ Insurgents have used "wit as a weapon"3 throughout human history. Making fun of opponents distinguishes inand out-group members. Thus, humour can be a medium to assert identities, unite activists, and encourage them to continue their struggle. Internally, conflicts within the movement might also be eased by changing to a lighter tone.

For the analysis of humour, a hitherto understudied aspect in the research of social movements, a distinction between the internal and external use of humour is essential. Social movements can be defined as separate spheres or subcultures that define themselves in contrast to their environment or aspects of that environment. Yet to make a difference, they act in public arenas. They mobilize for the purpose of protest and introduce novel knowledge into public discourses. Humour can play a role in both contexts - either as an internal mode of communication or as a way to go public (in other words, as a form of protest). In both environments, humour being "intimately related to conflict" 4 serves to illustrate what is at stake and where the front lines are. So, obviously, humour in social movements provides a rich source that allows the tracing of political struggles in everyday behaviour.

I. See, for instance, Hans-Jochen Gamm, Der Flüsterwitz im dritten Reich (Munich, I979), and Phil Taylor and Peter Bain, “'Subterranean Worksick Blues': Humour as Subversion in Two Call Centres”, Organization Studies, 24 (2003), pp. I487-I 509.

2. For the distinction between "reinforcing" and "subversive humour" see Janet Holmes and Meredith Marra, "Over the Edge? Subversive Humour between Colleagues and Friends", Humour, is (2002), pp. $65-87$.

3. Hans Speier, "Wit and Politics: An Essay on Laughter and Power", American Journal of Sociology, I03 (1998), pp. I352-I401, I354.

4. Harry H. Hiller, "Humor and Hostility: A Neglected Aspect of Social Movement Analysis", Qualitative Sociology, 6(1983), pp. 255-265, 256. 


\section{HUMOUR CHALLENGING WHAT?}

To assess the impact of the student movement in general and Spassguerilla in particular, one has to recall the postwar situation in West Germany. After 1945 , the nation that systematically murdered millions of Europeans and razed the continent to the ground was occupied in doing business. The initial attempts by the Western occupying powers to identify and prosecute Nazi perpetrators were abandoned early on for the sake of building a functioning economy and administration. Neither in public nor within most families were the crimes committed a major issue of discussion until the mid I960s. In this period, anti-communism served as a putty that united a great part of the West and allowed individuals to forget their collective involvement in unprecedented cruelties.

Not only was the Communist Party forbidden by the Constitutional Court in 1956, communism was used as a marker to discard most of the extra-parliamentary critique directed against the status quo. Peace-movement demonstrations opposing German rearmament in the mid I950s were subject to constant repression, as they were organized by communist groups, among others. Strict legal constraints on such demonstrations proved that freedom of political expression existed only on paper. Along with the restricted opportunities for political expression, German society was characterized by a conservative culture with few traces of the liberal traditions that had existed in the metropolises during the I920s. The role of women was restricted to childcare and housekeeping, premarital sex was considered a sin, and rock'n'roll music marked the decline of the West.

It was mainly these characteristics that defined the students' view of West German society. However, the rigid societal model of the Federal Republic was challenged by several developments in the I960s, of which the emerging student movement was only one. The sociologist Herman Korte described the changes in the Federal Republic as a "society in breakup". The formerly exclusive university system was opened up to larger numbers of young people; in the economy, the service sector expanded and both the conservative agrarian and the industrial milieus, which had generated their own specific identities, lost significance. Thanks to a wave of public sex education, the strict postwar morality was also trembling. In the cities, apolitical youth riots such as the Schwabinger Krawalle ${ }^{6}$ challenged the rules of public order. So when the student rebels entered the stage, the times had already been a-changin'.

5. Hermann Korte, Eine Gesellschaft im Aufbruch. Die Bundesrepublik Deutschland in den sechziger Jabren (Frankfurt, 1987).

6. The riots in Schwabing (a district of Munich) in June 1962 were triggered by a police operation against a couple of youths who performed music in public. Confrontations between the police and several thousand youths lasted for two days and resulted in dozens of injuries and 400 arrests. See Gerhard Fürmetz (ed.), Schwabinger Krawalle: Protest, Polizei und Öffentlichkeit zu Beginn der 6oer Jahre (Essen, 2006). 


\section{SPASSGUERILLA AS PART OF THE EMERGING STUDENT MOVEMENT}

The criticism of society that emerged among students meshed well with the changing architecture of postwar West Germany. However, its appearance was rather unexpected. In the early i960s, most students did not deviate from the conservative and authoritative norm. The vast majority were politically apathetic and an alarming proportion did not even embrace the idea of democracy. A group of social scientists reported that only io per cent of Frankfurt's students possessed a "definite democratic potential".? Nevertheless, a minority tried to understand the society they lived in with reference to psychoanalytical and neo-Marxist theory. Whereas traditional Marxists had focused their analysis on economic processes, this part of the postwar left emphasized the individual preconditions of liberation in everyday life. In the light of critical theory, the Federal Republic was considered totalitarian. Because it allegedly suppressed the libidinal energies of citizens and manipulated them, society was perceived not only as post-fascist but also as para-fascist. Harsh reactions to deviance and protest seemed to verify that interpretation. How did humour become a resource in such a serious confrontation between the youth on the one side and - in their view - the rest of society on the other?

Humour came into play when the reinvention of Marxism intersected with a subversive tradition in the arts. In 1964 a small group called Subversive Aktion brought together activists with very different histories. The first current consisted of drop-outs from the Munich bohemia, among them Dieter Kunzelmann, who would play an important role in developing Spassguerilla after his move to Berlin. As a group called SPUR, the bohemians had been part of the Situationist International, an antiorganization in the Dadaist tradition which understood society as a monolithic spectacle that could be challenged only by the alienation of everyday situations. ${ }^{8}$ In the early I960s, SPUR entered the public stage with several disruptive and provocative protests that attracted little in the way of persistent attention. Gaudi, a term for "fun" in south German dialect, played a central role in one of their manifestos. In the tradition of the artistic avant-garde, the group was inspired by a playful interpretation of reality and thus the identity of art and politics. Consequently, one of their claims was that "being creative means: having fun with everything in continuous invention".?

7. Jürgen Habermas et al., Student und Politik: Eine soziologische Untersuchung zum politischen Bewusstsein Frankfurter Studenten (Neuwied, 196I), p. 232.

8. See Peter Wollen, “The Situationist International”, New Left Review, I74 (1989), pp. 67-93, and Sadie Plant, Most Radical Gesture: The Situationist International in a Postmodern Age (London [etc.], 1992).

9. Jürgen Miermeister and Jochen Staadt (eds), Provokationen. Die Studenten- und Jugendrevolte in ibren Flugblättern 1965-I97I (Neuwied, I980), pp. I3-I4. 
The second current that fed into Subversive Aktion were students with an intimate knowledge of Western Marxism, who emphasized the liberation struggles in the global South as a window of opportunity for action in the metropolises. Two of them, Rudi Dutschke and Bernd Rabehl, had fled from repression in East Germany and consequently advocated an anti-authoritarian interpretation of Marxism. Both currents agreed upon a voluntaristic strategy that materialized in the group's name, Subversive Aktion. The slogan "Critique has to turn into action. Action reveals the rule of repression", ${ }^{10}$ written in a publication of the Munich strand, can be read as a motto for the whole student movement as it developed in the late i960s. Subversive Aktion considered direct action to be a prerequisite for raising ordinary citizens' awareness of the repressive society they lived in. This was part of the basic concept that the extraparliamentary opposition pursued: questioning the bourgeois public sphere and creating an independent counter-public. ${ }^{\text {II }}$

Later, the voluntaristic stance gained importance in the student movement as a whole and was spelled out in a "paper on organization" presented by Dutschke and Hans-Jürgen Krahl, an outstanding scholar of Theodor W. Adorno, at the delegates' conference of the student movement's core organization, the Sozialistischer Deutscher Studentenbund (SDS), in Frankfurt in 1967. ${ }^{\mathrm{I2}}$ The authors analysed West Germany as a society in which the rule of capitalism was realized in a totalitarian way using psychological means. Facing this monolithic system, Dutschke and Krahl introduced the concept of guerrilla to the context of protest in Western democracies. In their view, "the abstract violence of the system" should become "a sensual certainty [...] through visibly irregular actions". ${ }^{13}$ Students breaking the rules, and, of course, the authorities overreacting to this, were supposed to visualize the character of the given social order and thereby trigger changes.

Many activists took the actionist idea quite literally, testing the limits of the right of assembly in demonstrations and direct actions. A central aim of Subversive Aktion was to spread their ideas and contaminate other organizations with the strategy of breaking rules. With this goal in mind, the group's members decided to join the SDS in early 1965. This way, the conventional action repertoire of the organization would be supplemented by confrontational tactics. In the course of that year, the students'

ı. Unverbindliche Richtlinien, 2 (December 1962), reprinted in Frank Böckelmann and Herbert Nagel (eds), Subversive Aktion. Der Sinn der Organisation ist ibr Scheitern (Frankfurt, 1976), pp. 99-I2 I, I I 5.

I I. Karl-Heinz Stamm, Alternative Öffentlichkeit. Die Erfahrungsproduktion newer sozialer Bewegungen (Frankfurt [etc.], I988), pp. I7-53.

I2. Rudi Dutschke and Hans-Jürgen Krahl, "Das Sich-Verweigern erfordert GuerillaMentalität”, in Jürgen Miermeister (ed.), Geschichte ist machbar (Berlin, I980), pp. 89-95.

I3. Ibid., p. 94 . 
mobilization gained momentum, though admittedly only among a small number of them. In Berlin, the refusal of officials to let the critical journalist Erich Kuby speak in university rooms triggered demonstrations and a student strike. At the federal level, the planning of emergency laws that would legitimate the limitation of basic human rights was challenged by an alliance of trade unionists, left liberals, and students.

Beyond the national level, the war in Vietnam was the subject of numerous informational events and, in February 1966, of a street demonstration with 2,500 participants. In the aftermath of the demonstration, the actionist students succeeded in adding provocative symbolic elements to a traditional demonstration. At the Amerika Haus, some activists hung the United States flag at half mast and threw eggs at the immaculate façade. The repertoire of protest was also extended by forms of action that diffused from the US civil rights movement to Europe. Sit-ins and teach-ins were adopted in the academic environment. Similarly, the playful happenings of the Dutch Provos became known in Germany. The Dutch author Leo Klatzer, for instance, came to Berlin in December I 966 to report on the anarcho-spiritualistic protests in Amsterdam.

However, Kunzelmann and others opted for a humorous interpretation of the "guerrilla mentality". The emergence of Spassguerilla eventually became visible after another demonstration against the war in Vietnam on Io December 1966. ${ }^{14}$ The protest march, attended by 2,000 Berliners, demonstrated the limits of traditional forms of action. Since the march route did not go along any crowded streets, hardly anyone took notice of the demonstration. Two hundred participants who were dissatisfied with the otherwise invisible protest (among them members of Subversive Aktion $^{\text {IS }}$ ) passed into the central shopping area around Kurfürstendamm. Some of them mixed with Christmas shoppers, sang alienated Christmas songs, and chanted "Christmas wishes coming true, US bombs are brought to you". The police reacted hysterically and arrested anyone remotely suspected of being part of the protest. In a subsequent "walkabout demonstration", the aim of this scattered protest to unmask the rigidity of the authorities was made explicit: "This walkabout tactic seeks to deride the petrified legality, to reveal the irrationality behind the rational order, to show in a funny way that the role models in this society are fools." ${ }^{16}$

I4. For a description see Ulrich Enzensberger, Die Jahre der Kommune I. Berlin 1967-1969 (Munich, 2006), p. 93.

I 5. The group was then renamed the Viva-Maria Group, inspired by Louis Malle's film that portrayed the intervention of a French travelling circus in the Mexican Revolution (Viva Maria, F/IT 1965 ).

I6. A mobilization leaflet distributed by the group that later formed Kommune I, Archiv "APO und soziale Bewegungen”, Freie Universität Berlin, Fachbereich Politik- und Sozialwissenschaften, Otto-Suhr-Institut für Politikwissenschaft www.fu-berlin.de/APO-archiv (last accessed 29 May 2007) [hereafter, APO-Archiv], folder Kommune I. 


\section{KOMMUNE I AS A FOCUS OF SPASSGUERILLA}

In the context of Subversive Aktion, discussions focused not only on public action but also on the political consequences for the everyday life of activists. There was a consensus among the group that a realization of political ideals in private life was desirable. Since monogamy and family were perceived as supportive of a society that relied on authoritative structures and private property, some activists sought to challenge these traditions by living communally. While Dutschke and others withdrew to engage more intensely in the SDS, five men and two women eventually moved in together to share their apartment and their lives: on I January I967 Kommune I was born. This decision brought the centre of Spassguerilla to Berlin.

Understood in the sense of Che Guevara's theory of guerrilla warfare, the commune developed as a focus of Spassguerilla activity. Of course, Kommune I was not the only place where humorous actions were introduced to the student movement, but post festum we might say that energies to promote wit in politics were concentrated here and the conflict related to this issue condensed in this particular group. Still, one has to keep in mind that the primary objective of the commune was not to make fun of the authorities, but to integrate the private and the political in challenging the essentials of bourgeois life: wage work and family. However, in the public protests of the communards a humorous take on society came to the fore. This approach was promoted mainly by two individuals, Dieter Kunzelmann and Fritz Teufel, the latter joining the commune after his involvement in a late stage of the preceding discussions.

The notion of Spassguerilla, coined by Teufel, was not enshrined in a written programme. But most of the protests by the commune were inspired by the idea that the most adequate way to criticize society was to make fun of the routines and structures that reproduced it. While the communards aimed at changing their own lives in a prefigurative way of life, the Spassguerilla tactics were supposed to trigger reflections among the populace about the way society was organized and the rules individuals were following in their everyday lives. The commune's first year saw the most prominent of their humorous protests. We shall look at three of them in more detail to understand this kind of protest in context.

\section{The foiled pudding assault (April 1967)}

At first, the ideal of the communards to rid themselves of bourgeois dispositions resulted in a phase of soul-searching. Because several of the commune dwellers were dissatisfied with this kind of self-occupation, 
the collective decided at short notice to take action on the occasion of the visit of US Vice-President Hubert Humphrey on 6 April 1967. The plan to disrupt Humphrey's visit combined two tactics. First, the communards prepared smoke bombs to disrupt the presidential motorcade. This tactic had been successfully employed before by Dutch Provos to spoil the wedding of Princess Beatrix and her fiancé Claus von Amsberg in 1966. Second, they planned to deride the Vice-President with a symbolic act of maculation. Wheat flour, paint, and pies were bought as ammunition to be used against the motorcade. Rewriting the script was meant to deface the theatrical staging of respect for a world leader. With this protest, the communards hoped to recruit hitherto apolitical youths and reanimate those activists who were dissatisfied with conventional forms of protest. ${ }^{17}$

The plans for the assault could not be realized however. The political department of the police found the commune suspect from the very beginning and kept them under constant surveillance. When some of the communards tested the smoke bombs in a forest, they were arrested and their apartment searched. The police were convinced they had prevented a major crime, and the next day newspapers outbid each other with headlines reading "Humphrey meant to be assassinated" (Nürnberger Nachrichten, 6 April I967), or "FU [Free University] students produced bombs made of explosives from Beijing" (Berliner Morgenpost, 6 April 1967). Since the substances found in the commune proved harmless, the police had to release the detainees thirty-four hours after their arrest. The latter triumphantly called a press conference to deface the general hysteria by revealing their real plans. On this occasion, the communards added pudding, known to be Humphrey's favourite dessert, to the list of projectiles. ${ }^{18}$

The attempt to attack the US Vice-President made the commune wellknown in Berlin and in West Germany generally. Liberal mass media regarded the group as a symbol of rebellious youth who rejected the rules of their parents' generation and who tried to live accordingly. A TV team even let the communards re-enact their rehearsal for the attack in the forest in order to broadcast the scene. Paradoxically, given this media coverage the "pudding assault" became legendary in the student movement even though it never took place.

17. Rabehl reconstructs internal discussions with reference to two Kommune I folders confiscated by the police: Bernd Rabehl, Die Provokationselite. Der Sozialistische Deutsche Studentenbund und die sozialen Bewegungen in den soer und 6oer Jahren (Berlin, 1986), also accessible at http://userpage.fu-berlin.de/ archapo/Online/SDSPROVO.htm (last accessed 29 May 2007).

I8. Marco Carini, Fritz Teufel. Wenn's der Wabrheitsfindung dient (Hamburg, 2003), p. 4I. 


\section{Burn, warebouse, burn (May 1967)}

On 23 May 1967 the tabloid Bild reported a fire in the L'Innovation department store in Brussels. They described the inferno and the death of over 300 shoppers in detail. The report ended with testimonies of employees, connecting the blaze with anti-war protests in the days before the catastrophe. As the student movement in Europe was pacifist and had refrained from any violence, the commune understood the media coverage to be a strategy to defame their protest. ${ }^{19}$ In response, they designed several leaflets ironically supporting the implications of the newspaper. They exaggerated what had been suggested in the reports and claimed the catastrophe as a victory for the peace movement. In their leaflets, the communards announced arson as a new form of protest brought to Europe by Belgian activists:

Our Belgian friends have got the hang of getting the populace involved in the merry goings-on in Vietnam: They set fire to a department store, three hundred saturated bourgeois cease their exciting lives and Brussels becomes Hanoi. [...] If something starts burning in the time to come, if a military camp explodes somewhere, if a grandstand collapses in some stadium, please don't be surprised. Take it in your stride just as you did when the Yanks crossed the demarcation line, the city centre of Hanoi was bombed, the marines marched into China. Brussels gave us the only answer to this: Burn, warehouse, burn [original in English, echoing a slogan from the Watts riots in 1965$].^{20}$

Most of the leaflets were distributed on campus, but the police also got hold of a copy. A few days later the authors were indicted on charges of inciting violence. The media reaction to the leaflet was ambivalent. A commentary in Bild read: "Whoever glorifies this catastrophe that was probably started by radical leftist arson, and recommends copying it, should be put behind bars!" (26 May i 967). On the occasion of the trial, the liberal Spiegel took a different, more sympathetic view. Though the journalist did not approve of the content of the leaflet, he conceded that "the provocation succeeded. Society makes a fool of itself, exposes itself, reacts in such a way that the lurid attack abruptly becomes right" (I० July I967, p. 26).

The commune found their own way to deal with the absurd response of the authorities: quoting from the indictment, they published another leaflet that provided a pre-printed form which the recipient could use to officially invoke "the citizens of Berlin" to set a number of buildings on fire. ${ }^{21}$ Shortly after the "burn, warehouse, burn" leaflet was issued, a decisive event overshadowed subsequent developments, marking the

19. For descriptions see Enzensberger, Die Jahre der Kommune I; pp. I37-I44; Carini, Fritz Teufel, pp. 49-53.

20. Miermeister and Staadt, Provokationen, p. 28.

2 I. Ibid., p. 30 
beginning of the end of Spassguerilla as a prominent current within the student movement. On 2 June 1967 a peaceful demonstration against the visit of the Shah of Persia, Reza Pahlavi, was forcibly broken up by the Berlin police. The police pursued the protesters down back streets and shot dead one of them, Benno Ohnesorg. Police brutality against a harmless crowd was the most important event in drawing youths into the movement and radicalizing those already engaged.

\section{The Moabit soap opera (July 1967-March 1968)}

In the aftermath of the events described above, the guerrilleros of fun were offered a third public stage beyond happenings and leafleting: the courtroom. While the pudding assault did not result in legal consequences, two communards were charged for the "Burn, warehouse, burn" leaflet. At the Moabit district court, Fritz Teufel and Rainer Langhans turned the proceedings into a "soap opera" by bringing in their interpretation of the judicial procedures.

As early as 1964, Kunzelmann envisioned triggering "monster trials, through which we will make our ideas public". ${ }^{22}$ Once offered this stage, the communards did not play the roles that they, as the accused, were supposed to. In the light of the culprits' comments, courtroom routines ordinarily taken for granted seemed utterly absurd. ${ }^{23}$ Even the disciplinary punishment imposed by the judge was a source of joy for the communards. The judiciary insisted on taking evidence even though expert opinion underlined the literary character of the leaflet and rejected the idea it could be an incitement to violence. When the judge instead instructed a psychiatrist to render an expert opinion on the culprits' state of mind, Teufel asked the specialist if psychiatrists were familiar with the pathological need to impose penalties and if there was a therapy for that disease. In the end neither Teufel nor Langhans were convicted. Nonetheless, the Moabit soap opera received wide attention and led one theatre critic to characterize Fritz Teufel as "the most remarkable German playwright of the sixties". ${ }^{24}$

The most prominent statement poking fun at the judiciary, however, was uttered by Teufel during unfounded proceedings for a stone allegedly thrown on 2 June 1967. To question the rituals at court and their implicit affirmation of the authorities, he refused to stand up when the judges

22. Letter to Frank Böckelmann, 4 January 1964, printed in Böckelmann and Nagel, Subversive Aktion, p. I29.

23. A thorough analysis of the students' challenge to communicative rituals is offered in Joachim Scharloth, "Ritualkritik und Rituale des Protestes. Die Entdeckung des Performativen in der Studentenbewegung der 1960er Jahre", in Martin Klimke and Joachim Scharloth (eds), I968. Ein Handbuch zur Kultur-und Mediengeschichte der Studentenbewegung (Cologne, 2007), pp. 75 -88. 24. Cf. Carini, Fritz Teufel, p. 68. 


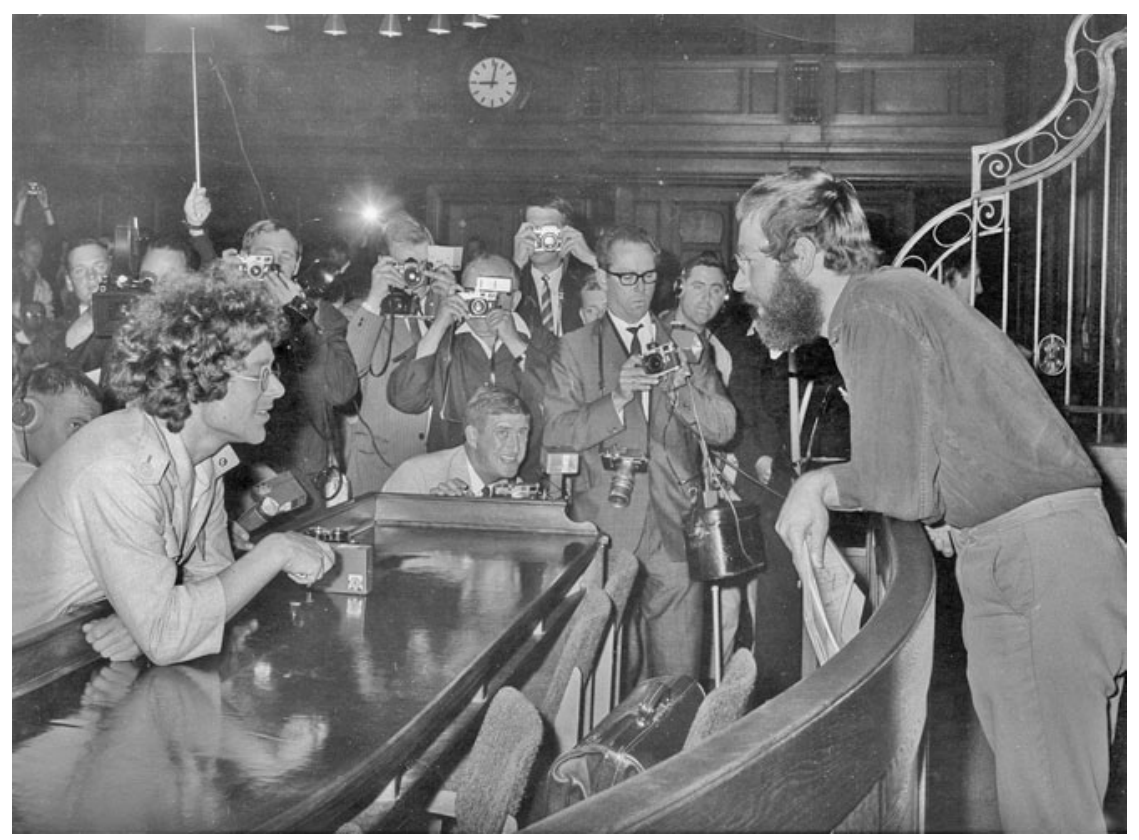

Figure I. The journalists' attention in the courtroom focuses on Rainer Langhans (left) and Fritz Teufel (right).

Photo: Ullstein-Lehnartz. Used with permission

entered the court. Having been asked to do so several times, he rose with the remark "If it serves to help establish the truth". This scene, covered by TV news and print media, became part of the collective memory as a metaphor of the anti-authoritarian revolt. The legal historian Uwe Wesel describes its consequences as follows: "The Federal Republic was laughing and it was a liberating laughter, namely the liberation from the authoritative manners in our courts". ${ }^{25}$

\section{SPASSGUERILLA IN CONTEXT: ADVERSARIES, MEDIA, AND AUDIENCE}

The concept of Spassguerilla developed in a historical context that has to be referred to in greater detail. The communards became icons of protest and, that attention guaranteed, they were able to disseminate broadly their critique of the status quo. This success was due mainly to opportunities they had in a society in breakup. First of all, the stage on which these Spassguerilla protests took place worked to their advantage. Berlin, which

25. Uwe Wesel, Die verspielte Revolution: 1968 und die Folgen (Munich, 2002), p. 64. 
was referred to as a "front city" in the time of the Cold War, had an intrinsically high iconic load. In this environment, symbolic, confrontational challenges to the anti-communist and pro-American consensus found fertile ground for resonance among citizens, the authorities, and mass media. Accordingly, protests making fun of what was central to most peoples' concept of meaning had a high potential for publicity. This does not, however, imply per se a dynamic evolution of the conflict. One has to keep in mind that the provocations organized by SPUR in the early I960s were framed as an impertinence of a group of lunatics.

The favourable conditions under which Spassguerilla could influence the way society was perceived were twofold. On the one hand, the vehement reaction to their humorous deeds demonstrated the frontlines in the conflict. The exaggerated rejection of the urge for change made clear who the enemy was. On the other hand, the iconic character of Spassguerilla supported the changes that were about to appear in West German society and increased doubts about the illiberal understanding of politics and life. Hence the protests fell on fertile ground, at least among some of the audience. While conservative media condemned the communards altogether, cartooning their "weeds and row" as a threat to "integrity, objectivity, clarity" (see Figure 2), more liberal outlets such as the weekly magazines Zeit and Spiegel had better intentions and presented the phenomenon as a signal for change. They underlined the lack of commensurability in the authorities' reaction to the behaviour of the communards and asked: "Does someone who is unruly have to be bonkers?” (Der Spiegel, I I March I 968, p. 68). The majority of the articles in liberal media partly embraced the critique of the communards and verified the ridiculousness of the authorities and conservative media.

The communards themselves were very aware of their dependency on media coverage. They included the reactions of the press in their plans; reading the news and collecting articles about the "commune of horror" (Bild) was part of their daily ritual. In retrospect, Fritz Teufel asserted that "we in particular, those who wanted to improve the world, needed the Springer press as much as the air we breathed". ${ }^{26}$ Vice versa, the Bürgerschreck [bourgeois horror] poster boys - chiefly Teufel, Kunzelmann, and their fellow communard Rainer Langhans - and their imagined counter-icon - the cheerless, authoritarian bourgeois - had much appeal for liberals who supported social change (not to mention advertisers).

While most of the assertions made thus far might also apply to the actionist current within the SDS, the specifically humorous interpretation of society contributed to the prominence of Kommune I both in the

26. Carini, Fritz Teufel, p. 44. The term "Springer press" refers to the conservative publisher Axel Springer, who had a dominant position in the Berlin media system with his newspapers Bild, B.Z., and Berliner Morgenpost. 


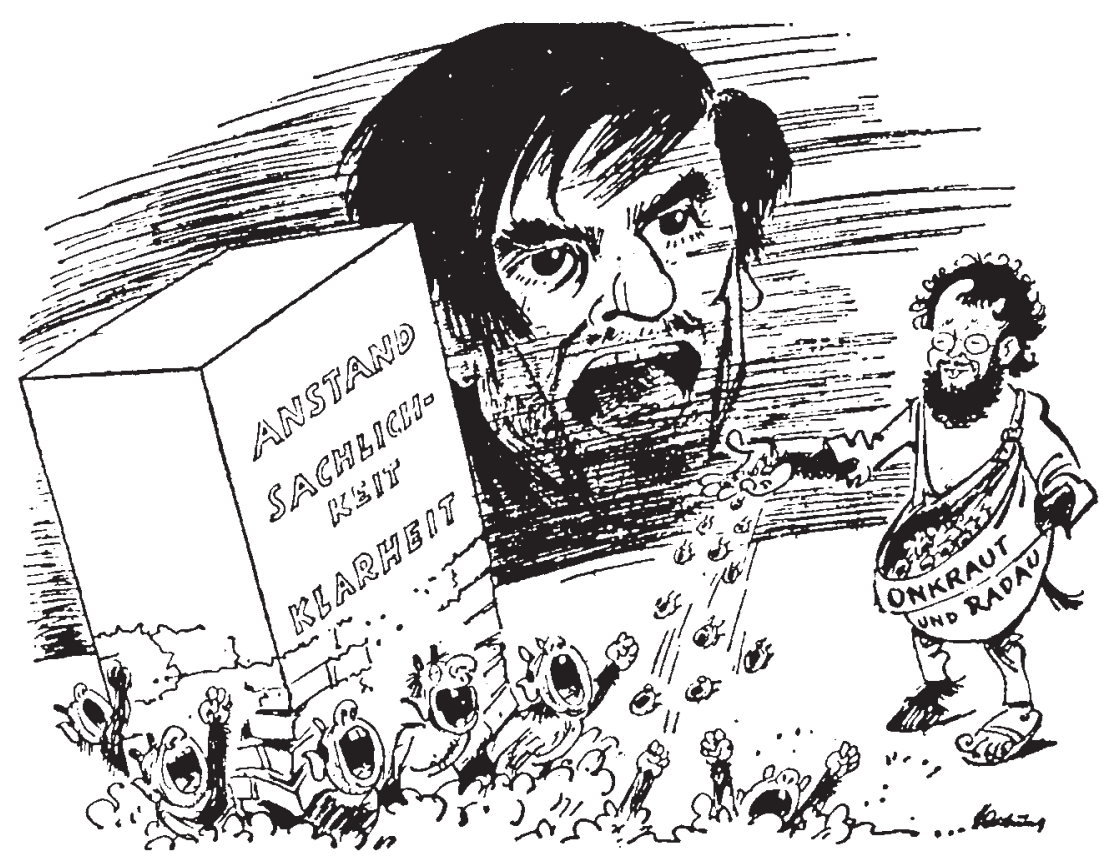

Figure 2. "The devil's (i.e. Teufel's) seed is growing” (in the background: Rudi Dutschke). Cartoon by Wilhelm Hartung, published in the daily newspaper, Die Welt.

contemporary perception of the student movement and, maybe even more so, in the process of historiography.

First, humorous protests provided a symbolically dense understanding of the situation. In the direct confrontation with the authorities and lawabiding citizens, the student movement aimed at producing a distance that rendered the targeted groups anachronous. The communards' derision of a seemingly absurd behaviour was immediately understandable. By contrast, the Marxist imagery of most students reinforced the rejection of their claims by Joe Public. This was also true in later decades. The further the process of liberalization advanced in West Germany, the more rejection of conservatism and authoritarianism became part of common sense. In contrast to the more traditional demonstrations of the students with an explicit socialist stance, Spassguerilla could be reduced to its hedonistic surface and be interpreted as making fun of anachronistic behaviour.

Secondly, the frontlines were not as definite as in the confrontations between protesters challenging the police. To take the police as an example, communards did not confront them violently; rather, they reinterpreted the function of a police officer. In a leaflet, they demanded sweets and contraceptives as new equipment and more time off for the 


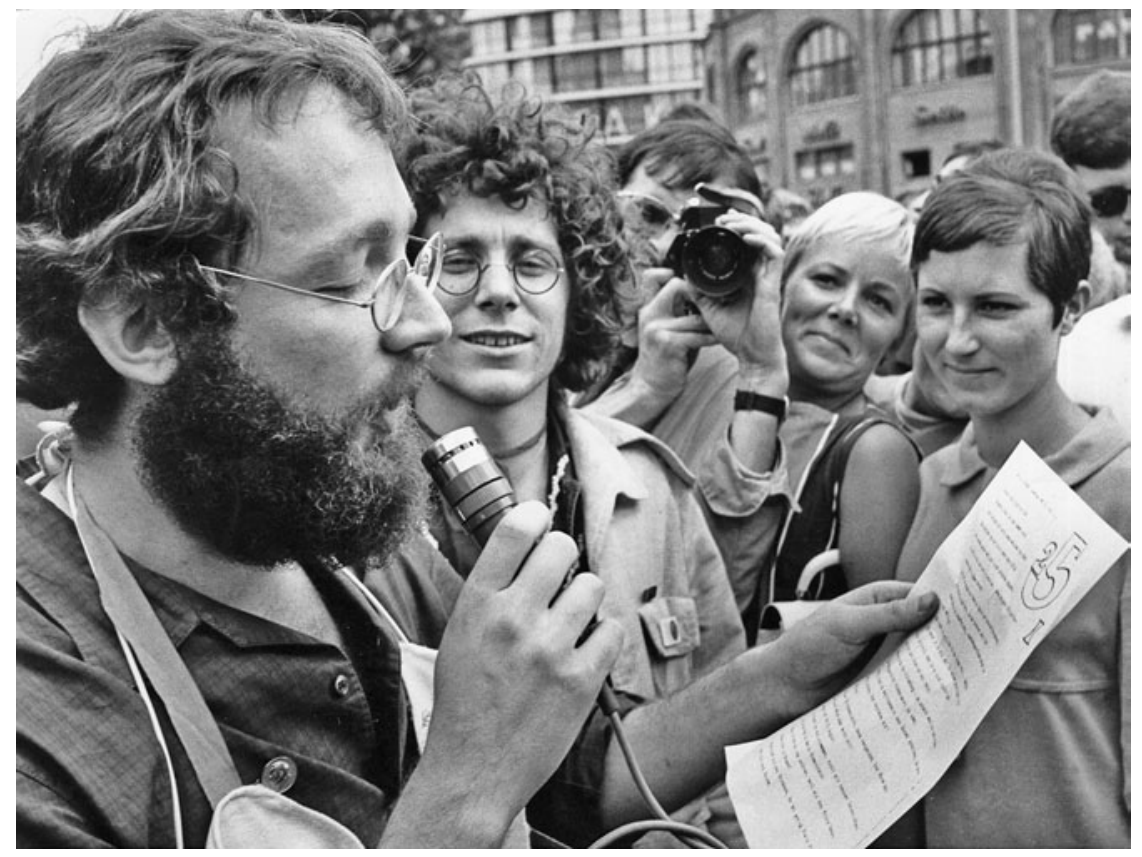

Figure 3. Upon his release from prison, Fritz Teufel reads a leaflet to bystanders and the crowd celebrating his regained liberty (I2 August 1967).

Photo: Ullstein-Lehnartz. Used with permission.

police to be tender with their girlfriends. ${ }^{27}$ The creation of ambiguity is also visible in the communards' communication with the audience of their happenings. When Fritz Teufel was released from prison, his comrades organized a fête on Kurfürstendamm. In order to unmask the aggressive excitement of passers-by, they distributed a leaflet that anticipated the bourgeois rage in detail. The text suggested shouting "Go to the East!" or "With Hitler this wouldn't have happened" - statements that were common in confrontations between rebellious students and their audience in the streets. ${ }^{28}$

\section{DYNAMICS WITHIN THE MOVEMENT}

First and foremost, Spassguerilla was part of the German student movement. However, most activists did not embrace their actions. In

27. Printed in Wolfgang Dreßen, Eckhard Siepmann, and Dieter Kunzelmann, Nilpferd des böllischen Urwalds. Situationisten Gruppe Spur Kommune I (Darmstadt, I991), p. 202. Similar claims had been raised before in the "white chicken plan" of the Dutch Provos.

28. Miermeister and Staadt, Provokationen, p. 34. 
fact, the tensions between comic actionism and the traditional concept of politics that had been at the centre of the SDS were only too obvious. In the early I960s, the SDS leadership stuck to a classical socialist stance, focusing on a Marxist analysis of political economy and, in the long run, on the proletariat as the revolutionary subject. Most of their work concentrated on theoretical reflection and university politics. The organization was perceived as outdated by the voluntaristic current of the movement which disliked the "tie-wearing Marxists". ${ }^{29}$ The prominent role the SDS took later in the confrontation with the establishment was mainly due to the influence of the actionist current. The traditionalists' critique of the voluntaristic approach in general and the misappropriation of the label "SDS" by Kommune I in particular led to the expulsion of the communards in May 1967.

The justification for this step revealed the fundamental strategic difference between Spassguerilla and the current represented by Rudi Dutschke which continued to gain ground within the SDS. The communards saw the confusion inherent in their humorous protests as a productive force to provoke dissident thoughts. Their idea of opposition was irreconcilable with the concept of rational exchange because they felt that the prevailing rationality was restrictive and excluded self-expression. Operating with this concept in mind, it is no wonder that Kommune I was among the nastiest disquieters of a discussion with the mayor of Berlin in December 1967. The SDS saw this counter-rationalist approach as a "desperation to possibly get their ideas across to anyone"..$^{\circ}$ By contrast, persuasion or "democratic argument" ${ }^{1}$ was the key for the bulk of activists within the SDS. Their strategy was purely rationalist, hoping for large-scale processes of enlightenment. Evidence that this idea lurked behind all confrontational action is the plan to issue a tabloid as a means of conveying the insurgents' view on reality. By contrast, Spassguerilla rested on ambiguity and non-identity. Alienating everyday situations was a way for them to trigger reflection about hidden power structures without presenting a proper interpretation of reality.

Even though there were significant differences between Kommune I, the actionist SDS, and the traditional left (within the SDS as well as the think tank Republikanischer Club), the positions were not mutually exclusive. Rather, the different strands were seen as complementary parts engaged in a common struggle. The SDS-led student council, for instance, rejected a demand by Berlin's mayor to distance itself from the pudding assault. Also, the expulsion of the communards from the SDS was supported by a narrow majority only. The search for new forms of protest

29. Dieter Kunzelmann, Leisten Sie keinen Widerstand (Berlin, I998), p. 5 I.

30. Kommune I, Quellen zur Kommuneforschung (Berlin, I968), not paginated.

3 I. SDS press release to justify the communards' expulsion from the SDS, undated, APOArchiv, folder Kommune I. 
resulted in "admiration" 32 for the commune. The symbolic load of Spassguerilla actions and their visibility in mass media contributed to shaping the identity of the student movement as an unconventional, antiauthoritarian revolt against an allegedly humourless establishment. ${ }^{33}$ The commune protests also resonated well beyond the hard-core activists. For quite a lot of newcomers, especially the non-academic, the public interventions of the commune as well as their hedonistic lifestyle were an incentive to get involved in the extra-parliamentary opposition. The humorous approach of the communards was partly echoed in support from the student community. The prosecutor in the process against Teufel and Langhans, for instance, received an open letter from a student who ironically praised the indictment as a heroic defence of the given order. ${ }^{34}$

By the time Benno Ohnesorg was shot dead on 2 June 1967, the actionist strategy became hegemonic within the SDS. While the death of the student was an important event in radicalizing the movement, it was also a challenge to the humorous approach to changing society. The murder of Ohnesorg and the attempted murder of Dutschke by a right-wing labourer who was influenced by the press coverage on the student movement evoked a perception that the adversaries were life-threatening. In this situation, humour did not appear to be an adequate way of communicating dissent and Spassguerilla protests waned. ${ }^{35}$ The serious turn taken by the student movement is mirrored in the name adopted by one guerrilla group that emerged in the I970s: the Bewegung 2. Juni [2 June Movement] bore the decisive date in its name.

The Spassguerilla mindset of denying rational exchange with a society allegedly infected by an oppressive ideology does parallel the irreconcilable approach of the emerging terrorist groups who defined themselves as "external" to West German society. ${ }^{36}$ Even if the leaflet on the occasion of the blaze in Brussels had no other implications than to ridicule the reaction of a hysteric tabloid, there is no denying that the first leftist terrorist act in I960s West Germany was an arson attack on two Frankfurt department

32. According to an article in the campus paper FU-Spiegel.

33. An article in the weekly Spiegel shows that humour was not the preserve of Kommune I and the policing of the student revolt was not universally repressive. To end a street blockade in Berlin, one police officer tried for two hours to demoralize the demonstrators with jokes remarkably after the escalation of 2 June 1967 . He promised that the police would play dance music if the students ended their protest, otherwise the police would present "trick fountains" (Der Spiegel, 30 October 1967, pp. 104-105).

34. Letter to senior prosecutor Kuntze, undated, APO-Archiv, folder Kommune I.

35. The position of comic action was also eroded by the rise of communist splinter parties, which abandoned the very idea of anti-authoritarianism that moulded the first phase of the student movement.

36. For an analysis of actionist groups between avant-garde art and terrorism see Thomas Hecken, Avantgarde und Terrorismus. Rhetorik der Intensität und Programme der Revolte von den Futuristen bis zur RAF (Bielefeld, 2006). 
stores by the core personnel of what later became the Rote Armee Fraktion. The most prominent Spassguerilleros themselves, Kunzelmann and Teufel, ended up sliding into terrorist groups. The latter asserted in an interview in I970 that the "clown Teufel is dead". ${ }^{37}$ The overlap of fun and violence was most obvious in the kidnapping of the conservative mayoral candidate, Peter Lorenz, in Berlin in 1975, of which Teufel was accused. This act combined the surrealist idea of disrupting an electoral process by disposing of one of the candidates with the evident ruthlessness of individual terror.

\section{CONCLUSION: HUMOUR IN THE STUDENT MOVEMENT}

Looking at the use of humour in acts of protest adds an important aspect to the cultural analysis of social movements. This must be particularly true for a protest phenomenon that refers to humour in its very label. The peculiarity of Spassguerilla in the context of humour in social movements is the public use of wit directed against authorities that were framed as outdated and humourless. Actions taken within this framework go beyond the interpersonal relationship that is characteristic of most everyday humour - political jokes for instance. In protests organized by the guerrilleros of fun, humour was an integral part. Thus, humour became more than a protest tactic: it was a strategic resource to question and delegitimize the given social order.

Analysis has shown that Spassguerilla was dependent on specific opportunities that allowed their protests to be received in the way they actually were. ${ }^{8}$ These opportunities were available only within a certain time frame. Spassguerilla made sense at a stage when the confrontation between the establishment and challengers had not turned overly violent. With the altered situation after 2 June 1967 , neither side could take a joke. Nevertheless, to varying degrees the public utilization of humour has become a consistent element in the action repertoire of many social movement actors in West Germany since the I960s. Over the course of time, such action has become differentiated to a great extent, ranging from fake electoral campaigns to alienated advertisements, from street theatre to fictitious events triggering real reactions. ${ }^{39}$ This amendment to the

37. Carini, Fritz Teufel, p. I46

38. Conditions favourable to humorous protests within transitional processes could also be observed in the final years of authoritarian communism in the 1980 , when humorous groups emerged. See Bronisław Misztal, "Between the State and Solidarity: One Movement, Two Interpretations - The Orange Alternative Movement in Poland", The British Journal of Sociology, 43 (1992), pp. 55-78; Padraic Kenney, A Carnival of Revolution: Central Europe 1989 (Princeton, NJ, 2002).

39. For a structuration see Simon Teune, "Wie ein Fisch im Wasser der Zeichenwelt. Spaßguerilla seit den I960er Jahren", in Dieter Rucht and Sven Reichardt (eds), Politischer Protest und Öffentlichkeit im 20. Jahrbundert. Studien zur Stenerung und Resonanz politischer Proteste in Deutschland (forthcoming). 
repertoire of action was hardly possible without influences from other countries. Spassguerilla is obviously a product of diffusion processes revitalizing protest in Western democracies. Through mass media and individual contacts, ideas for humorous protests spread from members of the Situationist International to the Dutch Provos, to the US Yippies, the Uccelli in Italy, and so forth. ${ }^{\circ}$

For Kommune I, wit was both an original expression of discomfort and a symbolic tactic to lament the status quo. Offering a dense symbolization of the lines that divided society, these protests were deciphered as meaningful by most of the actors involved: sympathizers, adversaries, media, and bystanders. Thus, this kind of activism had a significant impact on the image of the student movement in West Germany. The symbolic load of humour, however, certainly serves to exaggerate the actual weight of Kommune I as one actor among many in the movement.

Humorous protests to challenge a "humourless state" resonated within the society of the Federal Republic because their target was not totalitarian, as suggested by the protesters, but susceptible to change. Assuming that "a state's sense of humour is proportionate to the citizens' rights against the state, $[\ldots]$ the breadth and depth of political dialogue, and the degree to which state officials are legally constrained to tolerate public criticism" ${ }^{4 \mathrm{I}}$ there is evidence that West Germany learned to deal with the challenge of humour during the conflict. This was due especially to the fact that Spassguerilla was not universally rejected, but partly acclaimed as singing the right melody to make the ossified conditions dance.

40. Courtrooms, for instance, were used as stages to deride the authorities also in other countries. One of the best-known examples is probably the Chicago conspiracy trial that followed protests against the Democratic Party convention in 1968. See Pnina Lahav, Theater in the Courtroom: The Chicago Conspiracy Trial, Boston University School of Law, Working Paper Series, Public Law \& Legal Theory, Working Paper No. $02-16$ (Boston, 2002).

4I. M. Lane Bruner, "Carnivalesque Protest and the Humorless State", Text and Performance Quarterly, 25 (2005), pp. I36-I55, I37. 